\title{
Drawing Dangerous Women: The Monstrous-Feminine, Taboo and Japanese Feminist Perspectives on the Female Form
}

\author{
Sara Sylvester ${ }^{1 *}$
}

Published: April 11, 2020

\begin{abstract}
During the twenty-first century, global developments with graphic texts have seen positive changes in the representation of characters and storylines representing female-led narratives and perspectives. Recent Japanese graphic texts offer an instructive window into concerns about feminist comics and graphic novels which not only represent a vital intervention in terms of contemporary Japanese feminist politics but also reinforce their relevance as feminist art activism within a global frame. Taking into account the popularity of manga worldwide this article argues that the growing range of Japanese texts with clear feminist messages marks an intervention on behalf of female creators in keeping with the theory and practice of contemporary feminist discourse. Additionally, this Japanese evolution illustrates the ways in which second wave feminism, particularly feminist art, has impacted women on a global scale. Consequently, the article explores the important role of intersectionality alongside themes relating to the body and sexuality, subversion of the monstrous feminine, feminist activism by considering the narrative of Rokudenashiko's graphic memoir What is Obscenity?: The story of a good for nothing artist and her pussy (2016).
\end{abstract}

Keywords: Monstrous-feminine, manga, memoir, feminist activism, kawaii

\section{INTRODUCTION}

During the twenty-first century, developments in graphic texts have seen positive changes internationally in the representation of characters and storylines representing female-led narratives and perspectives. Recent Japanese graphic texts offer an instructive window into concerns about feminist comics and graphic novels which not only represent a vital intervention in terms of contemporary Japanese feminist politics but also reinforce their relevance as feminist art activism within a global frame. This article brings into question the political utility of manga as a platform for feminist resistance.

The case study chosen in this article, featuring Megumi Igarashi's (under the pseudonym Rokudenashiko) graphic memoir What is Obscenity?: The story of a good for notbing artist and her pussy (2016) provides an opportunity to consider the form's potential as a cross-cultural medium, whilst also marking an increase in female characters and female-led titles in Japan. What is Obscenity? (2016) is a collection of short comic strips that originally appeared in the liberal newspaper Shukan Kinyobi (The Japan Times). Each short comic strip is interspersed with text sections which provide the reader with more information about Japanese law, the criminal justice system and Japanese media. As a multimodal text, it also includes embedded photographic images as well as an interview with the film director Sion Sano. The narrative documents Igarashi's arrest on December 3, 2014 for alleged violation of Japanese obscenity laws - she became 'the first woman in Japanese history tried on grounds of obscenity as spelled out in Article 175 of the Criminal Code of Japan' (McKnight, 2017: n.p.). The narrative describes her confinement, and continued activities after her release, before backtracking to tell the story of how Rokudenashiko became a 'vagina artist' (see Figure 1). It is important to note the significance of the term 'manko' at this stage, and its taboo status in Japan, since the word is used throughout the manga memoir not only to refer to herself - 'I am MANKO (vagina) artist' (Rokudenashiko, 2016: 4) - but also importantly in relation to one of the central characters of the manga, Ms Manko. In terms of reception, building upon her newsworthiness after her arrest and trials, What is Obscenity? (2016) both in Japan and internationally has furthered Rokudenashiko's international reputation as an artist and activist. 
Rokudenashiko's graphic memoir (see Figure 1), which could also be referred to as a graphic biography, graphic book, comic book, picture novella or 'autographics' (a term coined by Whitlock, 2006) will through this study be identified as a graphic memoir or more aptly, manga memoir, since it can be perhaps perceived as 'the most important narrative mode of our contemporary culture' (Miller, 2000: 423). Whilst 'the graphic memoir genre is not yet as established as it is in the West' (El Refaie, 2012: 6); this article asserts that the text could also be identified as a manga memoir since Rokudenashiko's book highlights the 'flowering of the graphic memoir genre' (El Refaie, 2012: 223) in Japan. It also signifies the international power of this sub-genre which 'occurs now across cultures in a global network of sequential art' (Whitlock, 2006: 969).

Taking into account the popularity of manga worldwide, this article argues that the growing range of Japanese texts with clear feminist messages marks an intervention on behalf of female creators, which is in keeping with the theory and practice of contemporary feminist discourse. It also argues that this Japanese creative evolution illustrates the ways in which second wave feminism continues to impact women on a global scale. However, it is important to clarify from the outset that this article is not discussing second wave feminist activism as such, but rather focusing on how feminist art practice continues to challenge stereotypical gender roles.

By specifically focusing on the power dynamics presented through Rokudenashiko's text, this article considers how gender roles, female sexuality, and the rise of the Japanese feminist movement can be exemplified through the graphic memoir format. Through a detailed close textual examination of What is Obscenity? (2016) taking a critical feminist perspective, this research seeks to determine the importance of women-led graphic novels and comics as well as mark their continuing evolution in Japan. The author chosen for this research reflects a contemporary work that firstly, has been successful in mainstream society and secondly, has drawn global media attention. Consequently, this research asserts that Rokudenashiko's depiction of women, the female form and femininity in this graphic memoir can highlight the ways in which graphic novels are intricately embedded in the complex interaction between gender, globalisation and nationalism. Equally, the impact of second-wave feminisminfluenced art can be clearly identified through the ways in which the style, medium, narratives and representations of women are presented in What is Obscenity? (2016). As a multimodal text, Rokudenashiko's representation of 'manko art', communicated through a combination of modes, will be discussed in detail through the consideration of female genital art from a feminist perspective with a specific focus on the work of artist Hannah Wilke (1940 1993), and what psychoanalytic theorists such as Julia Kristeva (2002) and Barbara Creed (1986) have labelled the 'monstrous-feminine'.

Comparisons can be drawn between the approaches both Wilke and Rokudenashiko adopt through their 'performalist' self-portraits, particularly when considering the ways in which both artists through their work reclaim the female form, whilst also satirising patriarchal taboos surrounding female genitalia. This provides a starting point in order to explore the influence of Wilke's work on a global scale, second-wave feminism's continued influence on comics, and the importance of graphic memoir in relation to the idea of 'I become my art, my art becomes me' (Wilke, 1975). Clear similarities can be drawn between both artists' use of their bodies to demystify the female genitalia - from Wilke's signature vaginal sculptures created in terra cotta, porcelain and latex, to Rokudenashiko's vulva sculptures which have included works such as a chandelier, a remote control car, necklaces and iPhone cases, as well as the infamous kayak ${ }^{1}$. In this context the Japanese artist furthers the feminist activist art movement to transform stereotypes through the form of the Ms Manko diorama which has been mass produced as manga, figurines and stuffed animals in her attempt to influence traditional Japanese cultural attitudes.

In a similar way to scholarly discussion of the representation of women in horror films (Creed, 1986) the treatment of women in comics has also been discussed for many years (Simone, 1999; Murray, 2011; Cocca, 2014) primarily focusing on the objectification of women, and their portrayal as overtly sexual, submissive and inferior. Taking the stance that patriarchal ideologies have impacted the ways in which women are depicted in manga and comics globally, Rokudenashiko's use of 'cute' manko exemplifies how the 'monstrous-feminine' as a feminist creation can accentuate the significance of gender and female sexuality. Ms Manko personifies the 'cute' or kawaii style popularised in Japan. Whilst the widespread use of the term kawaii is quite a recent phenomenon, Sharon Kinsella plots its expansion between the 1970s and 1990s, defining the term kawaii as 'essentially mean[ing] childlike' (Kinsella, 2013: 220) and associating it with a range of attributes such as: 'sweet, adorable, innocent, pure...vulnerable, weak and inexperienced social behaviour...' (Kinsella, 2013: 220). The hyper-cute kawaii Ms Manko humorously subverts the deadly symbol of the vagina dentata; a narration that is repeated throughout the comic strips within the book as a mischievous play on the fear of castration and protest against traditional Japanese attitudes to the public representation of female genitalia. Subsequently this research aims at addressing the following questions:

1. What is the significance of Rokudenashiko's use of manga memoir, as a multimodal medium, in presenting an experiential reportage depiction of real events?

${ }^{1}$ Rokudenashiko was arrested in July 2014 and found guilty of breaking the Japan's obscenity laws in 2016 after she distributed data that enabled recipients to make $3 \mathrm{D}$ prints of a kayak modelled on her genitals. 
2. How does Rokudenashiko construct her identity and that of Ms Manko in her narrative, in order to enact feminist activism?

The article will begin with a historical overview and literature review of western feminist art, graphic novels and memoir narratives. Then, Fairclough's (2013) critical discourse analysis framework will be adopted, drawing on visual and textual discourse and social theories. Through critical discourse analysis, feminist ideologies found within What is obscenity? (2016) are uncovered. This is achieved by following Fairclough's three-dimensional model of critical discourse analysis in which the text is socially positioned. During the first decades of the twenty-first century, comics studies has developed significantly, as have the research methods of textual interpretation used, which have encompassed formal, semiotic, and narratological as well as cultural, historical and political analysis (Bramlett, Cook and Meskin, 2012; Chute, 2008; 2010; Duncan, Smith and Levitz, 2015; Gardner, 2012; Groensteen, 2007, 2013). Taking a multimodal critical discourse analysis approach (CDA) following Fairclough $(1993,1995,2013)$, a three-dimensional model was adopted as the main analytical framework. Through the use of micro and macro analysis, a CDA framework allows the opportunity to examine in depth the intricacies of 'the production, distribution and consumption of a text' (Fairclough, 1995: 135). The findings suggest that secondwave feminist ideologies prevail in this manga memoir. Finally, a call for a multi-modal analysis is made as it would better represent the language - text and image - found in graphic novels and comics.
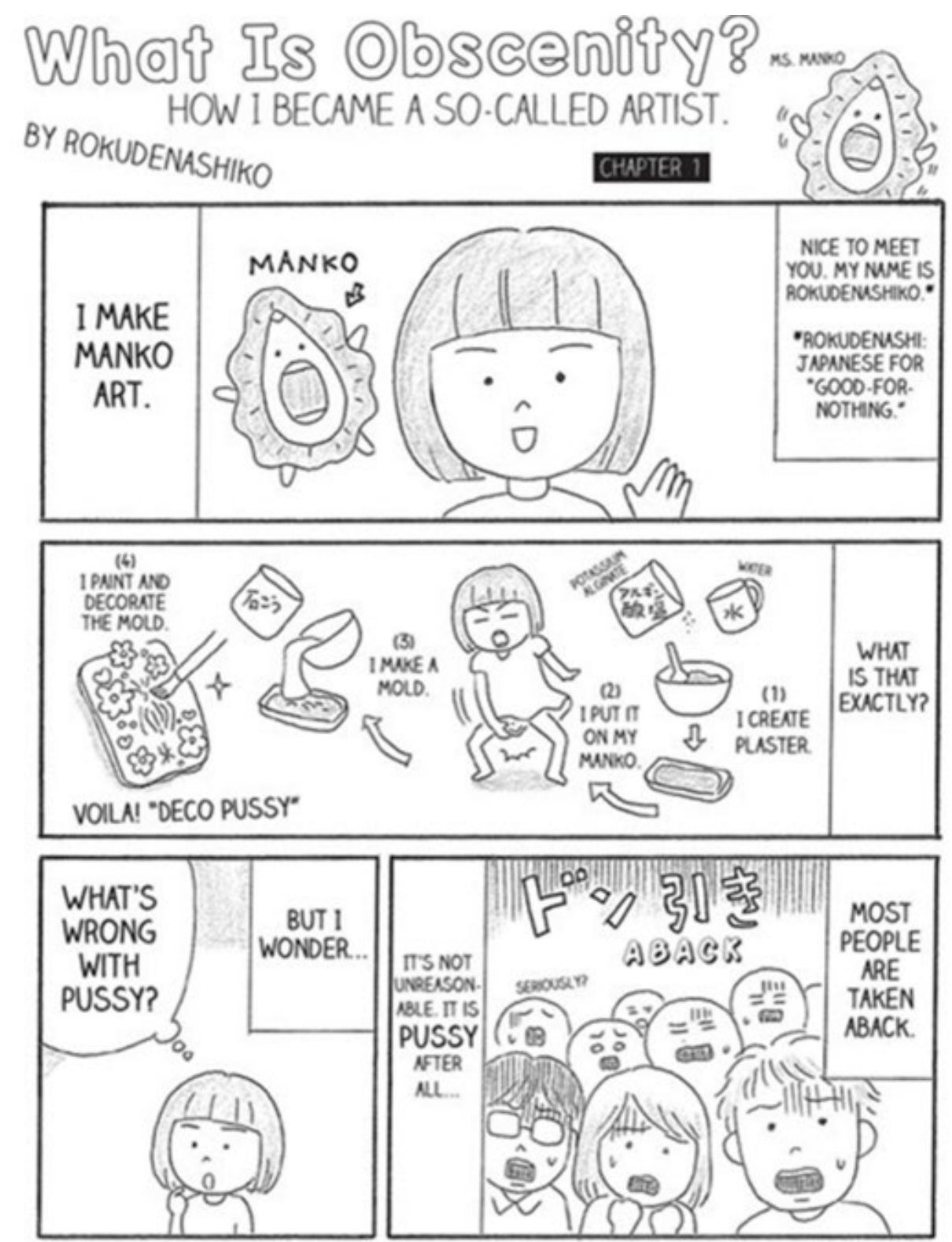

Figure 1. 'I make manko art', Chapter 1 from What is Obscenity?: The story of a good for nothing artist and her pussy. Rokudenashiko. 2016. (C) Rokudenashiko. 
The content of What is Obscenity? (2016) suggests a continuation of Max Skidmore's (1983) assertion that the comic medium is both a mirror and instigator of social change. Both are potentially important here, as Rokudenashiko's text is not simply a reflection, but a critical intervention in Japanese society that engages with her national and international readership. Rokudenashiko's text is not only an exemplary appropriation of manga which extends the narrative representation of feminist activism, but, through the depiction of the kawaii mascot, the character of Ms Manko also subverts the 'monstrous-feminine' (see Figures 1, 3 and 6). The artist, through her graphic novel, disrupts patriarchal mythologies of cultural misogyny in order to highlight Japan's hypocritical views of male and female genitalia. The work in turn demonstrates the continued importance of the body for women artists and highlights the influence of second-wave feminism in relation to sexual politics and the demystification of female sexuality.

Consequently, I will suggest that Rokudenashiko's manga memoir signifies important implications for researching the relationship between graphic texts produced by female creators in Japan, and the global influence of feminist visual representations of women; I also explore how these are located within the context of Japanese culture, and the history of graphic narrative texts.

\section{HISTORY OF JAPANESE GRAPHIC NOVELS AND COMICS}

It is necessary to begin with a brief account of the historical background of Japanese manga, since 'the nature of comic art makes the form ideologically interesting' (McAllister, Sewell and Gordon, 2001: 3). This is followed by a detailed examination of the themes and ideology in Rokudenashiko's work to illustrate the ways in which she provides a feminist critique and vision within Japan.

Firstly and significantly, ' $\mathrm{o}] \mathrm{f}$ all the productions of Japanese popular culture in the second half of the twentieth century, perhaps the most well-developed and commercially important has been comic art: manga magazines and books...' (Thorn, 2004: 169). By the end of the twentieth century, the largest comics industry in the world was found not in the United States, but in Japan (Sabin, 1993: 199).

Japan has 'a thriving comics culture' (El Refaie, 2012: 6); currently a trend in popular culture worldwide, the term 'manga' refers to comics that originate from Japan. Certain conventions employed in manga are different from that of western comics, for instance it is important to note that traditional Japanese manga reads from right to left, the reverse of western comics and graphic novels, which read from left to right. In original manga-style books, the action, the word bubbles, and sound effects are all written in this direction. In Japan, manga's success can be attributed to low production costs (with the exception of covers, they are usually printed in black and white) and a diverse range of genres and audiences which can be simply categorised into four kinds: 'shonen' for boys, 'shojo' for girls, 'seinen' for adults, and 'rediisu komikeku' for women.

Simply defined, manga is the title given to Japanese comics, a medium that has developed into a global cultural product; its impact as a medium is unquestionable since it appeals to an exceptionally diverse range of audiences (Bouissou, 2008). Kinsella identifies manga as a medium which 'carries an immense range of cultural material' (Kinsella, 2005: 3). Kinsella's examination of post-war Japanese cultural politics through adult manga specifically considers the ways in which national political discourse has been mediated through this form and has provided a vehicle to question social taboos. Out of this has grown a broad range of Japanese graphic novels and comics; however, of most interest is shöjo manga, a genre aimed primarily at a young female audience, typically characterised by a focus on personal relationships. It is the visually distinctive style of shöjo that will be considered in more depth in relation to Rokudenashiko's manga memoir, in order to consider the disruptions of masculine language and symbolism, to represent a kind of écriture féminine (Kristeva, 2002).

From this position this article will consider the ways in which What is obscenity? (2016), as a manga memoir, depicts a valid representation of 'authentic, home-grown, modern Japanese culture with its roots in Japanese social experience' (Kinsella, 2005: 3). The graphic memoir, as a sub-genre, has made a significant contribution to comic production globally, exploring a 'variety of genres and covering every topic, subject, and experience under the sun: from LGBTQ autobiographies, histories of slavery, and PTSD memoirs to journeys of forced migration, war-torn communities, and global upheavals, among many others' (Aldama, 2019: 3). Memoir and personal narratives have long been established as key points for feminist artists and scholars to contest dominant movement narratives, recast and reclaim conventional gender stereotypes, and use their experiences to refine movement ideas and goals (Taylor, 2008). Whilst autobiography is, and continues to be, a successful sub-genre in the form of graphic memoir, particularly for western feminist comic artists such as Alison Bechdel, Jennifer Hayden, A. K. Summers and Una, as indicated earlier, 'it is not yet as established [in Japan] as it is in the West' (El Refaie, 2012: 6).

Just prior to the critically acclaimed debut of the graphic memoir Persepolis (Satrapi, 2008), Malek (2006) identifies such texts as a 'phenomenon of the memoir genre' thus reinforcing the continued popularity of this form, hybridised by feminists, and demonstrating how 'memoir gives its readers an author as guide, an informant whose presence lends a unique perspective to the historical moment' (Adams, 1999: 8). Indeed, exploration at the 
end of the twentieth century of the popularity of women-produced memoirs is signalled by Carolyn G. Heilbrun's assertion that '[w]omen have only recently begun in large numbers to recount their lives' (Heilbrun,1999: 35). Similar to graphic novels in the early twenty-first century, such as Marjane Satrapi's successful Persepolis series, Rokudenashiko's What is Obscenity? (2016) demonstrates the global interest in memoirs which 'have been experiencing a great surge of popularity' (Malek, 2006: 360).

With the growth of female manga creators in Japan, there is a clear resurgence of manga memoirs as a way to present alternative female voices and subvert dominant cultural narratives. Rokudenashiko's manga memoir is identified by McKnight (2017) as directly influenced by experiential reportage which is defined as 'documentary in its depiction of real events, but focaliz[ing] the story through a writer's eyes, body, and pen' (McKnight, 2017: n.p.). As a feminist activist text, Rokudenashiko's 'first-person voice compounds the fact-finding impulse of reportage with the highly interpretive visual and story conventions of shöjo manga' (McKnight, 2017: n.p.). Taking the stance of Alan Moore that '[a]ll comics are political' (quoted in Sabin, 1993: 89), the question concerning how graphic novels and comics fit in with the socio-political context of Japan, given the different ranges and roles in which these texts operate, is of high ideological importance particularly for the role of alternative voices such as Rokudenashiko in the creation of resistant, cultural-identity-based feminist activism.

\section{THE INFLUENCE OF SECOND-WAVE FEMINIST POLITICS IN JAPAN}

Feminist perspectives on art first surfaced alongside the Women's Liberation Movement in the 1970s, from a combined involvement in political activism in the contemporary art world and critiques of the historical traditions of the arts. As Meskimmon puts it:

Current feminist art theory remains engaged with the body, but works with embodied subjectivity to explore alternative conceptions of women's agency... New approaches to 'the body' help us to rethink the past histories of women's art practices as much as to produce critical work on contemporary art. (Meskimmon, 2008: 389)

This field developed alongside postmodern debates about culture and society that have taken place in many academic disciplines in the last fifty years through the questioning of western patriarchal dominance. Lippard's assertion that "Feminist art" is a political position... It is also developing new forms and a new sense of audience' (Lippard, 1980: 362) demonstrates the continuing importance of a feminist approach to contemporary art theory, which is associated with a persistent need to critically examine the issues surrounding western traditional values and theories when engaging with art, in order for them to be addressed and challenged by feminist artists and scholars alike.

Lippard's article reflects upon how the re-evaluation and critique of these values opened up possibilities to question the art world structures and power relations that were dominant in the 1970s. It was at this time that artists, frustrated with the existing structures of the art world, instigated the creation of an alternative scene in which they had control over the type of art they created and how it was exhibited. This led to a blurring of the boundaries between what the art world considered fine art and other art forms, as artists, particularly women, began to experiment with performance, photography, video art and book art. Through these alternative artistic modes and via exploration of popular culture, an array of approaches was fostered that developed concepts such as post-minimalism and conceptualism. Now seen as the beginnings of post-modernism, women played a significant role in the questioning of dominant ideology and breaking down the barriers of the traditional art world. The feminist movement played a crucial role in the development of postmodernism, particularly through art. Women artists formed collectives and through unified sisterhood began to reject the established art canon (Pollock, 2013: 23) which led to the consideration that whilst '[d]ifference is what it's all about, [it's] not just gender difference' (Lippard, 1989: 29) thus signalling how women artists signalled intersectionality, and were not only concerned with issues of gender but also with race, ethnicity and sexuality.

The feminist art movement, in perceiving that ' $\mathrm{f}] \mathrm{eminism}$ is an ideology, a value system, a revolutionary strategy, a way of life' (Lippard, 1980: 362) focused on the fact that few women were represented in galleries and museums and that they were excluded from the canon of art history, all of which greatly influenced their own contemporary art practice. Feminist content argued that gender is socially, rather than naturally constructed. Other devices used to subvert the hegemonic notions of high culture were produced by the validation of art forms not considered high art, such as craft, video and performance art. Many feminist artists explored an aesthetics that arose out of female experience - the female body, women's history, and individual autobiography. 'The 1970s might not have been "pluralist" at all if women artists had not emerged during that decade to introduce the multicoloured threads of female experience into the male fabric of modern art' (Lippard, 1980: 362) Furthermore, the feminist 
art movement, which had distrusted the cult of genius and questioned the classification of greatness, thus placed an emphasis on the concept of pluralist diversity rather than traditionally held beliefs (Pollock, 2001: 23-39).

In refuting the universalising narrative of male humanist art, feminist art theory widened the boundaries of the field of study, it is clear that the radical idealism of the 1970s has continued to inform feminist art practice into the twenty first century. It is perhaps pertinent here to acknowledge criticisms of the cultural politics of the second wave (Evans, 1995; Brooks, 2002; Zack, 2005), namely, that earlier generations over-emphasised white, middleclass, heterosexual women's experiences and discounted the viewpoints of women of colour, poor, queer, lesbian and transgender women as well as women from the non-western world. According to Lise Shapiro Sanders, 'third wave feminists have come to emphasise the diversity of women's experience over the similarities amongst women,' with a particular focus on addressing the inadequacies of second-wave ideology for dealing with women's experience beyond its 'white, middle-class biases' (Sanders, 2007: 7).

The image of the female body has long been a disputed issue for feminists of different generations in which 'each wave of feminism has fought its own battles of body image' (Richards, 1998:196). Whilst the first two waves fought to establish women's rights and further advance women's status accordingly, for feminist waves that have followed the importance of diversity of individual identity has placed 'image and body (...) at the centre of feminist analysis' (Richards, 1998: 196) encouraging women to define femininity for themselves, celebrating the diversity of sexualities, femininities, in order to further the idea of empowerment.

Similar to the rise of the feminist movement in the west during the 1960s and 1970s, a women's liberation movement, 'üman ribu, typically known as ribu' (McKnight, 2017: n.p.), also emerged in Japan from the New Left and radical student movements. The influence of the feminist movement in Japan by the end of the 1970s, similarly to the United States, Europe and the United Kingdom, focused on labour, sexuality and equality (Mackie, 1988: 63). However, whilst their high-profile activities attracted significant media coverage, protests were often ridiculed and attracted little public sympathy. Nevertheless, the legacy of such feminist activity, has unquestionably furthered the advancement of feminist debates in contemporary Japan (Gwynne, 2013: 326).

Whilst there has been scholarly attention examining the aftermath of second-wave feminism in contemporary Japan, particularly in terms of the current state of twenty-first century feminist activism (Gwynne, 2013); Chilla Bulbeck has noted there is a tendency within hegemonic feminist discourse to perceive feminist activism as a distinctly western form of politics (Bulbeck, 1998). As Kano (2018) asserts 'it is not easy to define what the term "feminist" might mean in Japan today' since, according to Mina Roces, throughout most of the twentieth century Asian women activists have "disliked the word "feminism" because of its association with a western vision of feminism (Roces, 2010: 1). In view of all that has been mentioned so far, one may agree with Joel Gwynne (2013) who justifiably argues "that any polarisation of "Western" and "Asian" feminisms is highly problematic and reductive’ (Gwynne, 2013: 326).

With this in mind and by drawing on the cultural significance of manga as a product to expose gender bias, I will now turn to situate Rokudenashiko's creation of manko art and Ms Manko within an academic discourse on feminist activist art.

\section{THE BODY, THE MONSTROUS-FEMININE AND HANNAH WILKE}

Beginning with Simone de Beauvoir's pioneering work, The Second Sex (1949), where approaches to the understandings of sexual difference that focus on the phenomenology of embodiment have been developed within feminism in a much more subtle and complex way, we can understand her concept of sex difference. Within this feminist phenomenological focus on anatomical difference as shaped by social norms, sex is perceived not as an essentialist concept but, rather, selects one significant aspect of social location. With this in mind it is important to acknowledge that art is typically made with and appreciated through the body. It is the body that has been the preferred subject matter of the visual arts throughout history, thus it is quite logical to presume sex, realised in this way, would make a difference to the appreciation and production of art.

French feminist philosophy that emerged in the 1970s was more focused on 'the body' exemplified in the work of Hélène Cixous who explored the concept of écriture féminine; they argued that writing and philosophy are phallocentric, therefore focusing on 'writing from the [female] body' as a subversive exercise in response to this (Cixous and Clément, 1975; Irigaray, 1985). Although Luce Irigaray's approach to writing the body differs from Cixous's perspective, both scholars envisaged parallel systems that singularised a female-centred creativity which was distinct from androcentric or humanistic (read: male) styles. Their ideas of the 'feminine' have proven invaluable in the development of wider feminist thought.

Feminist art challenges the traditional norms of art, of the oppositional trope of male subjectivity/female objectivity. It questions what it means to speak of 'female experience' in relation to the production of art, enquiring instead what a specifically 'feminist' art practice might be, and in doing so examining how women artists have tried to circumvent the problem of the objectification of the female body. Much has been written about women artists 
and their focus on the personal, as well as the feminist focus on women's identity (Nochlin, 1971; Jones, 1998; Pollock, 2005; Knafo, 2009; Meskimmon, 2012). An essential aim is to gain artistic autonomy without being incorporated into a masculine aesthetic. To gain this autonomy, many women artists have had to, and continue to, challenge the negative construction that women are inferior. It is important, for the contextualisation of contemporary female artists and for the acknowledgement of their achievements to be aware of these aims. These concerns are still valid today, as contemporary women artists not only produce art works with feminist content, but very likely get them accepted by art institutions due to the foundations that were newly laid by their female predecessors.

Disruption of the female body, an aim that was influenced by the sexual politics of second-wave feminism, can also be observed in feminist film theory. Continuing the focus on the female body an iconic source has been Barbara Creed's The Monstrous-Feminine (1993). Creed, through the critical analysis of horror films examines the ways in which women are represented as victims; simultaneously, she argues that the prototype of all definitions of the monstrous is the female reproductive body. She picks up on the 'vagina dentata', a primal myth discussed by Freud (1909) in the castration complex, suggesting that women's genitals contain teeth. Specifically, Creed asserts the castrating vagina evinces the 'monstrous-feminine' or 'what it is about woman that is shocking, terrifying, horrific, abject' (Creed, 1993: 1).

Another key influence on feminist artists is Wilke (1940-1993), through her exploration of the body and in her consideration of female identity. The nude body is omnipresent in her work and its self-representation is the vehicle by which Wilke exposes personal and political themes. Her use of female body imagery played a crucial role in feminist art criticism in the 1970s. In her series of photographs entitled S.O.S - Starification Object Series 1974 -1982, Wilke used her nude body as a backdrop with vulvas randomly stuck to her body that have the appearance of scars. S.O.S. attacked the physical representation of women and more importantly their derogatory treatment in society. Wilke parodies popular images of women in this series of photographs, while her glamorous and seductive guises simulate those of traditional advertisements and pin-up poses of women, the viewer's eye is drawn away to focus on these scar marks covering her body. This series of work openly questions the ways in which women's bodies are objectified; Wilke's body presents a paradox - on the one hand, an object of desire for men - whilst also evincing the distasteful and repellent.

Wilke's work disturbed relationships between the self and the other in performance, a practice that has continued to drive other feminist artists across all creative mediums also intent on challenging the dominant scopophilic binary. 'U]sing her body as statement became a trademark of Wilke's work' (Tierney, 1996: 45) and there are strong links between the works of Wilke and Rokudenashiko's in their exploration of the body in performance, where the artist's own body and life is employed as material, in this case through a graphic novel. 'Rokudenashiko's works draw on parts of this history, such as personal liberation and making life experience the grounds for liberation' (McKnight, 2017: n.p.). Rokudenashiko redeploys Creed's notion of the monstrousfeminine in a specific challenge to the Japanese taboo surrounding female genitalia. In her kawaii, Ms Manko, a figure presented in her manga memoir, is a good example, its monstrous cuteness menaces patriarchal Japan in an attempt to liberate women's sexual agency.

The analysis now turns to Kress and Van Leeuwen's (2006) social semiotic framework of visual communication which asserts that the three metafunctions of linguistics can be extended to visual communication. From this stance, the image is perceived to be a resource for complex representation (Kress and Van Leeuwen, 2006). Multimodality provides a framework for visual communication and a useful way to measure and evaluate the ways in which images play significant roles in meaning making and for examining the interrelationships between communicative modes. Equally, in her useful discussion of the visual and verbal interpretive skills required for scholarly work on the comics, Whitlock (2006) stresses the importance of the 'vocabulary of comics' where 'its grammar is based on panels, frames, and gutters that translate time and space onto the page in black and white' (2006: 968). 

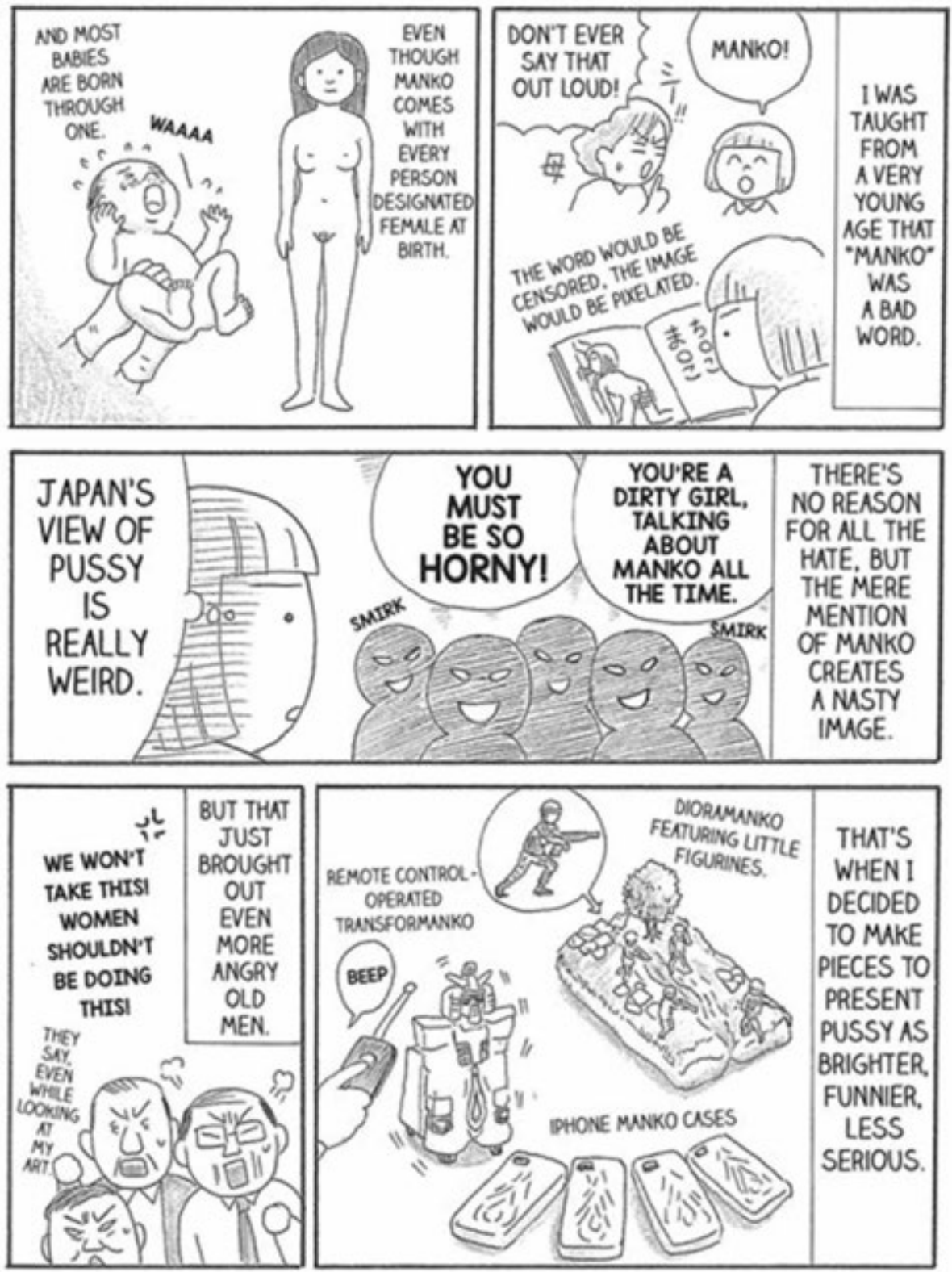

Figure 2. 'And most babies are born through one', Chapter 1 from What is Obscenity?: The story of a good for nothing artist and her pussy. Rokudenashiko. 2016. (c) Rokudenashiko.

\section{VISUAL AND TEXTUAL ANALYSIS OF ROKDENASHIKO'S WHAT IS OBSCENITY?}

Throughout What is Obscenity Rokudenashiko draws herself simply, as a happy, smiling woman, similar to representations of her in photographs within the book (see Figure 1). This contrasts with her Japanese pseudonym which is translated as 'Good for nothing'. The character Ms Manko makes her appearance in the first comic strip and is the first image with which the reader is confronted. Outside the frame, anchored in the right-hand side of the comic strip title, Ms Manko's mouth is always fixed as wide-open, almost in a sign of protest, which is incongruent with her 'cute' representation. One explanation for this construction could be the appropriation of kawaii culture (Kinsella, 1995) as a medium for political protest; whereby the artist presents female genitalia as a fictional cute character to signify the openness and naturalness of the female body. Ms Manko is simultaneously taboo yet also distinctly kawaii, acts as an embodiment of positivity, thus becoming a symbol of feminist resistance.

In a panel that demonstrates the way Rokudenashiko creates her art, she poses, partially squatting, to imprint plaster onto her genitals. She adopts the classical artistic convention of using flowers to decorate her 'deco pussy'. On the other hand, the last panel on page 8 (Figure 1) illustrates a mixed crowd's response to the artist's manko work. Men are portrayed as reduced to a dark mass of sinister entities in Figure 2, which anchors their derogatory comments - 'horny', 'dirty girl'. Figure 3 continues to characterise men as opposed to the artist's work, whilst the characterisation of Rokudenashiko sitting demurely as the police confiscate her art works is juxtaposed with the speech bubbles of her repeatedly saying 'manko'. The taboo nature of the word is characterised through the men's 
reactions to her, and later by the panel of the policeman laughing, and joking that 'We're hot boxing manko' which adds to the absurdity of the situation for the artist and reader. Figure 6 depicts a press conference where Rokudenashiko is characterised in a serious manner, openly questioning Japanese society as she states that she is an artist with a mission'. Rokudenashiko portrays herself using a very simple and iconic manga style. Similarly, Ms Manko is illustrated in a comparable style. Aesthetically, the drawings cannot be considered elaborate: it is in their simplification of the facial features through which they can achieve 'universal identification' (McCloud, 1994: 36). Given the universal reach and appeal of Japanese manga globally, the kawaii depiction of Ms Manko further strengthens this position of generalism.

Given that the comic strips in the text are largely black and white, colour, or lack thereof, still serves textual, cultural and social functions, as it is a 'semiotic mode' in making meaning (Kress and Van Leeuwen, 2006: 344). Indeed, the use of black and white graphics supports the traditional style of manga. The cover of the text, like traditional manga, is coloured. It is important to note that What is Obscenity? (2016) is unusual I in that it includes coloured photographs, the magazine front covers of Shukan Kinyobi [The Japan Times] documenting Japanese public protests, as well as a final comic strip in full colour titled 'This is my story' (2016: 167). When analysing the colours used in the manga memoir, it is assumed colours are both 'expressionistic' and 'iconic' (McCloud, 1994:188) and function to semiotically link the memoir narratives and the identity of the artist. The cover of What is obscenity? (2016) features the image of a Ms Manko diorama, presented in soft pastel pink colours against a bold turquoise background which establishes a focus on Rokudenashiko's manko artwork. Panchanathan et al. (2000) claim that colours can be used for gender role socialisation: the pastel colours used on the front of and in the text thus reinforce the childlike and kawaii image, as well as femininity. Such presentation of Ms Manko could be considered as subverting the usual demure and submissive kawaii representations in order to question traditional societal norms.

What is Obscenity? (2016) is a typical example of a comic in which gutters are used to separate different scenes in adjacent panels so readers can easily interpret the narrative and make sense of changing scenes between panels. By merging the panels across the gutters, the effect of Rokudenashiko's account of events is speeded up. Since this graphic memoir can also be labelled as a multimodal text layout, features associated with traditional manga graphic novels and comic strips which are typically printed in black and white - are disrupted through the inclusion of montage, of photographs, passages of text and excerpts from interviews.

In the second dimension of Fairclough's three-dimensional CDA framework, discursive practice involves considering how texts are constructed, circulated and interpreted, hence CDA analysis usually draws on conversation analysis and pragmatics (Fairclough, 1995). However, such an approach is not suitable for analysing Rokudenashiko's multimodal manga memoir, in which conversations are rarely present. Therefore, the analysis will focus on how the text was produced based on Rokudenashiko's autobiographical practices in which her and Ms Manko's personalities and identities can be discursively interpreted.

\section{CHARACTERISATION OF ROKUDENASHIKO AND MS MANKO}

Rokudenashiko introduces herself, her art practice and activism in a Foreword in What is Obscenity? (2016). At the end of this preface, she encourages herself not to express doubt but simply go ahead. The book is divided into five sections, documenting chronologically the events that led to her arrest, confinement and court case; it concludes with a comic strip from the perspective of Ms Manko detailing the events. The development of Rokudenashiko's emotional response to proceedings can be seen gradually, as the narrative develops: initially at times humorous, (Figures 1 and 3), the narrative also includes traumatic and frightening lows during her confinement which lead to the slow burning build-up of anger and determination to demystify female genitalia in Japan (Figures 4-6).

\section{SOCIAL RELATIONSHIPS AND PRACTICES}

The visual characterisation of Ms Manko and Rokudenashiko is similar in style, throughout the text, both character's open mouth implies protest and possibly one of continued shock and distress. Graphic novels and comics are richly laden with such codes by means of 'reductive iconography', by which both the artist and reader depend on stereotypes to communicate (Royal, 2007: 7; Eisner, 2008). Given the nature of Rokudenashiko's art work and its documentation in her manga, particularly through Ms Manko, this inevitably reductive iconography is utilised to its full potential. The significance of What is Obscenity? (2016) lies in the way in which the manga memoir as feminist activism reflects the impact of social structures, as well as in the narrative construction of principal characters. 
Just as western feminist artists in the 1970s used their bodies as material to convey cultural statements whilst also simultaneously causing 'middle-class outrage at public nudity' (Tierney, 1996:45), Rokudenashiko similarly documents through her graphic novel the outraged responses by Japan authorities to her explicitly feminist art based on her own vulva, for which she was arrested and stood trial (see Figures 2 and 3). Barry and Flitterman's (1980) consideration of how feminist artist practice can work towards productive social change acknowledges the 'importance of giving voice to personal experiences; the expression and documentation of women's oppression as well as their aspirations' by identifying four categories in the 'typology of women's artmaking' (1980: 35-36). Similarly to Wilke, Rokudenashiko's work could be interpreted as a 'glorification of an essential female power' (1980: 37). Rokudenashiko's graphic memoir as an artwork that has as its aim to document her experiences, thus turns her into a subject, rather than an object for the male gaze, challenging conventional notions of, and taboos around, female sexuality.

Rokudenashiko's graphic novel What is Obscenity? (2016) is part of a larger graphic memoir phenomenon. What is obscenity? (2016) is a prime example of Japanese feminist activist production (see Figure 6) as a site for experimentation within various genres - here, that of art, memoir and graphic novel. Rokudenashiko's What is Obscenity? (2016) is a unique form of Japanese feminist activist production, in that it blends the genres of memoir and graphic novel to present the narrative of Rokudenashiko as a feminist political and cultural activism.
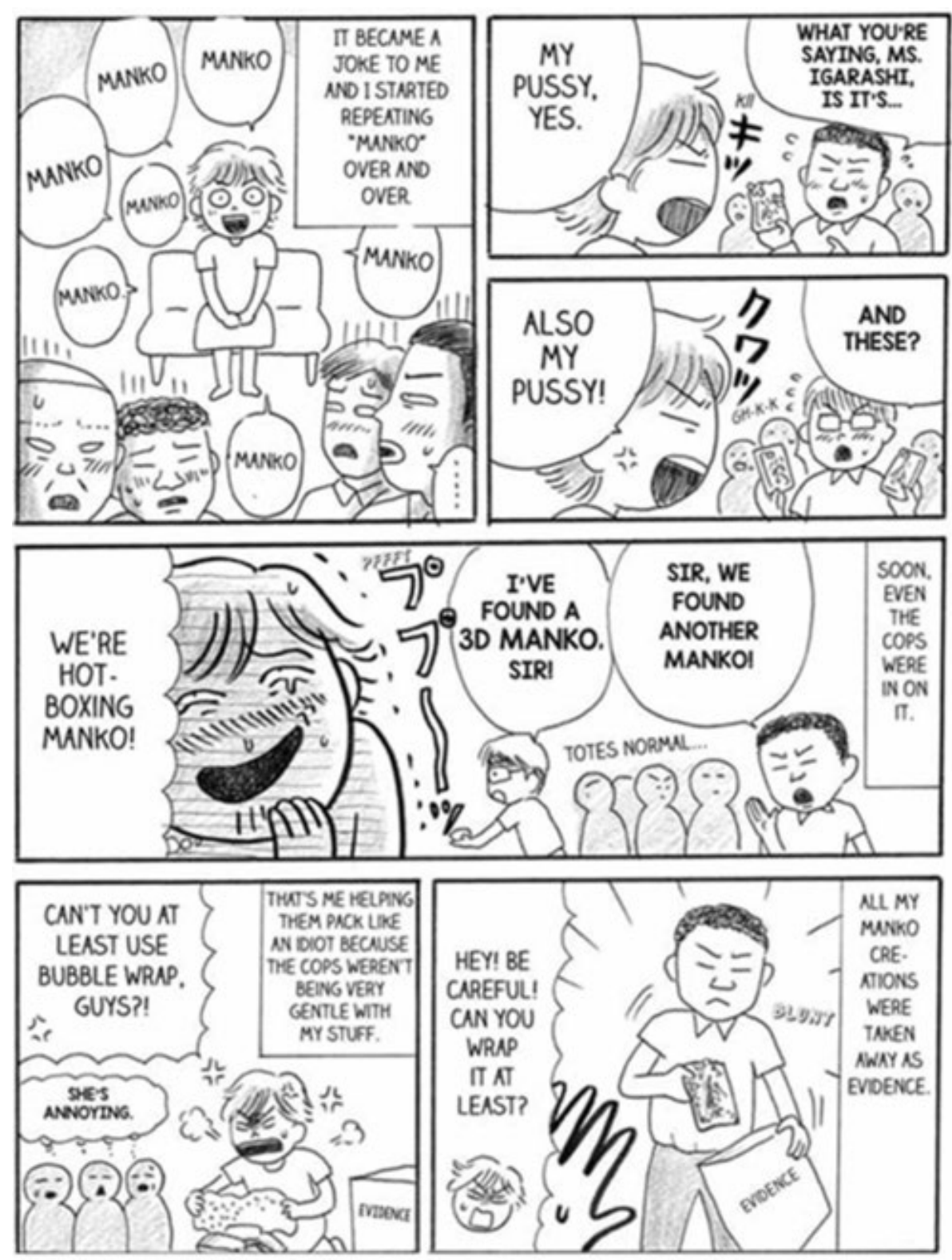

Figure 3. 'Manko. Manko...', Chapter 2, from What is Obscenity?: The story of a good for nothing artist and her pussy. Rokudenashiko. 2016. (C) Rokudenashiko. 
Rokudenashiko's drawings provide resonance for Japanese and non-Japanese readers alike whilst also recalling the importance of the manga genre, as well as the historical importance of the arts within Japan. Such an amalgamation reflects the importance of Japanese comic and graphic novels not only from a national but a global perspective. Rokudenashiko's What is Obscenity? (2016) use of graphic memoir allowed feminist protest about Japanese culture, through blending western feminist art with Japanese manga. Rokudenashiko's graphic memoir has enabled new hybrid cultural forms to emerge which are influenced by second-wave, western feminist art, but also Japanese graphic novels and comics.
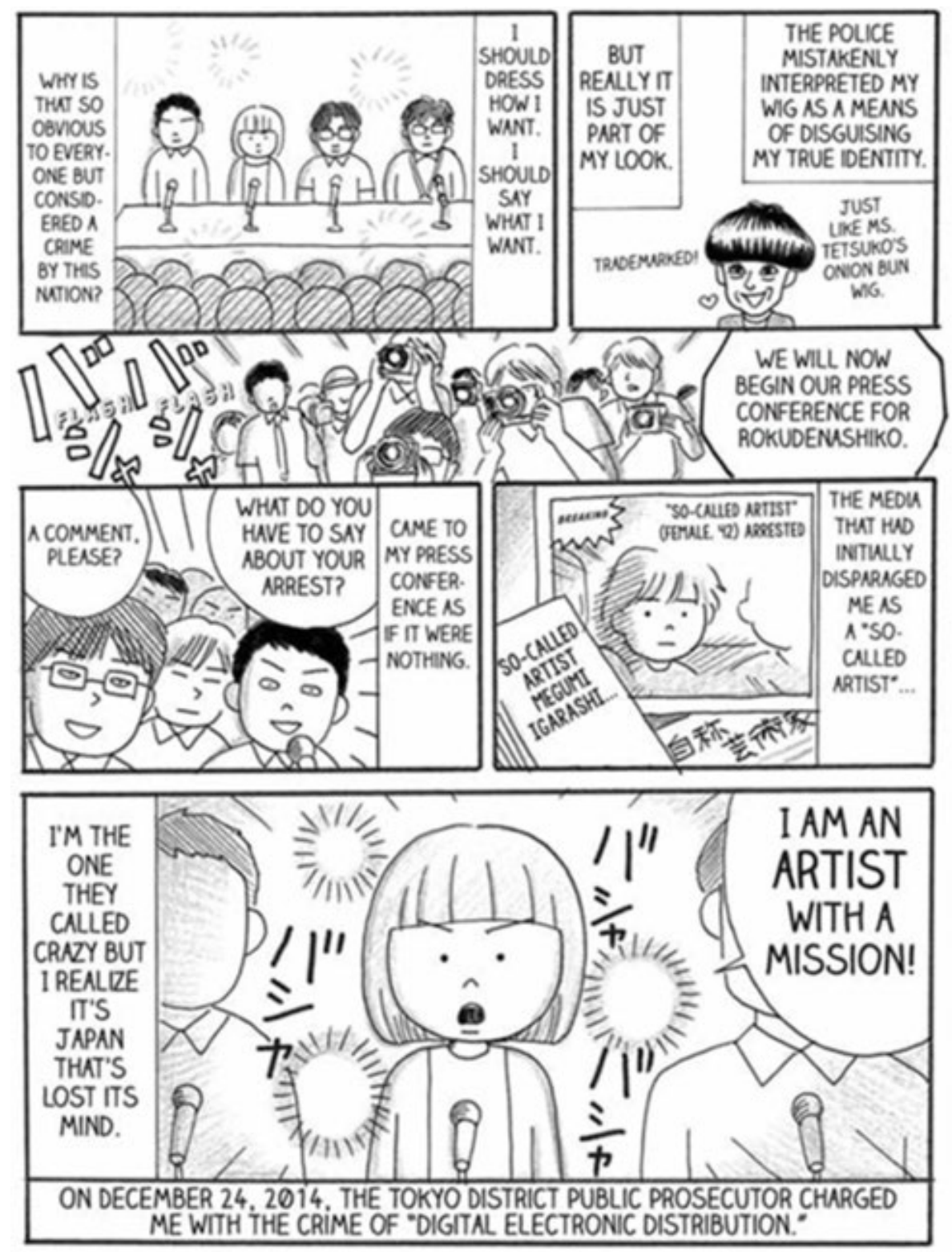

Figure 4. 'I am an artist with a mission', Chapter 17 from What is Obscenity?: The story of a good for nothing artist and ber pussy. Rokudenashiko. 2016. (C) Rokudenashiko.

Rokudenashiko's graphic memoir demonstrates the power that the graphic novel wields in Japan as an activist or subcultural instrument, thus embodying the concept that

[w] omen are shedding the skin of respectability and the conventions designed for them by men, or by men for themselves. In the process, they begin to write of what they know, and not of what they are allowed to know, or expected to know, or, above all, permitted to tell. They will inevitably annoy many male readers (Heilbrun, 1999: 42).

Rokudenashiko's subversion of 'cute' and her reclaiming of manga's representation of the female body is certainly a powerful force that has successfully shaken and annoyed the patriarchal establishment (see Figure 6). Rokudenashiko's manga memoir, in a similar way to Marjane Satrapi’s Persepolis (2008) put into focus the hypocrisy 
of Japan's laws in relation to perceived female acts of obscenity and allowed the artist to address issues of the representation of women, highlighting the double standards in relation to female genitalia.

The English translation is bound in the original Japanese right to left format, thus reflecting the traditional style, tategaki, of writing. Whilst the beautiful manga style drawings depict the serious central theme of Japan's conservative stance toward female sexuality, Rokudenashiko also incorporates within the text elements of kawaii$k e i$, cute style, a sub-genre of manga which are customarily directed at a young female audience. The hyping of kawaii styles within Japan as well as globally constitutes part of a countercultural subversion of mainstream styles. Ms Manko, whilst appealing to the kawaii aesthetic of 'sweet' and 'adorable', also subverts this because of what Ms Manko directly represents - the female genitalia. As a provocative protest symbol of manko, art is neither vulnerable nor weak. Taking the premise that 'Cute is one element of the vast popular culture which has flourished in Japan...overwhelming and threatening traditional culture' (Kinsella, 2013: 252), Rokudenashiko, through her depiction of Ms Manko utilises kawaii as a form of popular culture focused on escapism and nostalgia to explore traditionally held Japanese perceptions of female sexuality. Kawaii signifies worship of the childlike; Miki Kato asserts that ' ...cute fashions idolise childhood because it is seen as a place of individual freedom unattainable in society' (Avella, 2004: 214). Thus Ms Manko, as a 'cute' representation of female genitalia, not only acts as a mascot for Rokudenashiko's identity as a manko artist, whilst asserting individual freedom; the character also signifies her protest against the hypocrisy of Japanese obscenity laws where 'Even the utterance of manko was a taboo, and absolutely forbidden since I was a child, and I've found myself respecting the archaic convention against saying it, even despite myself' (Rokudenashiko, 2016: 4).

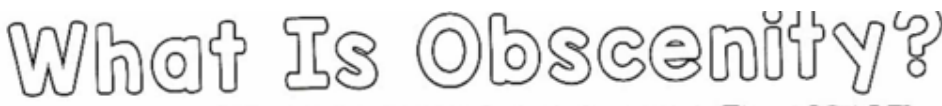

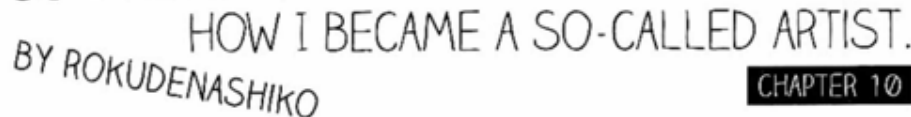
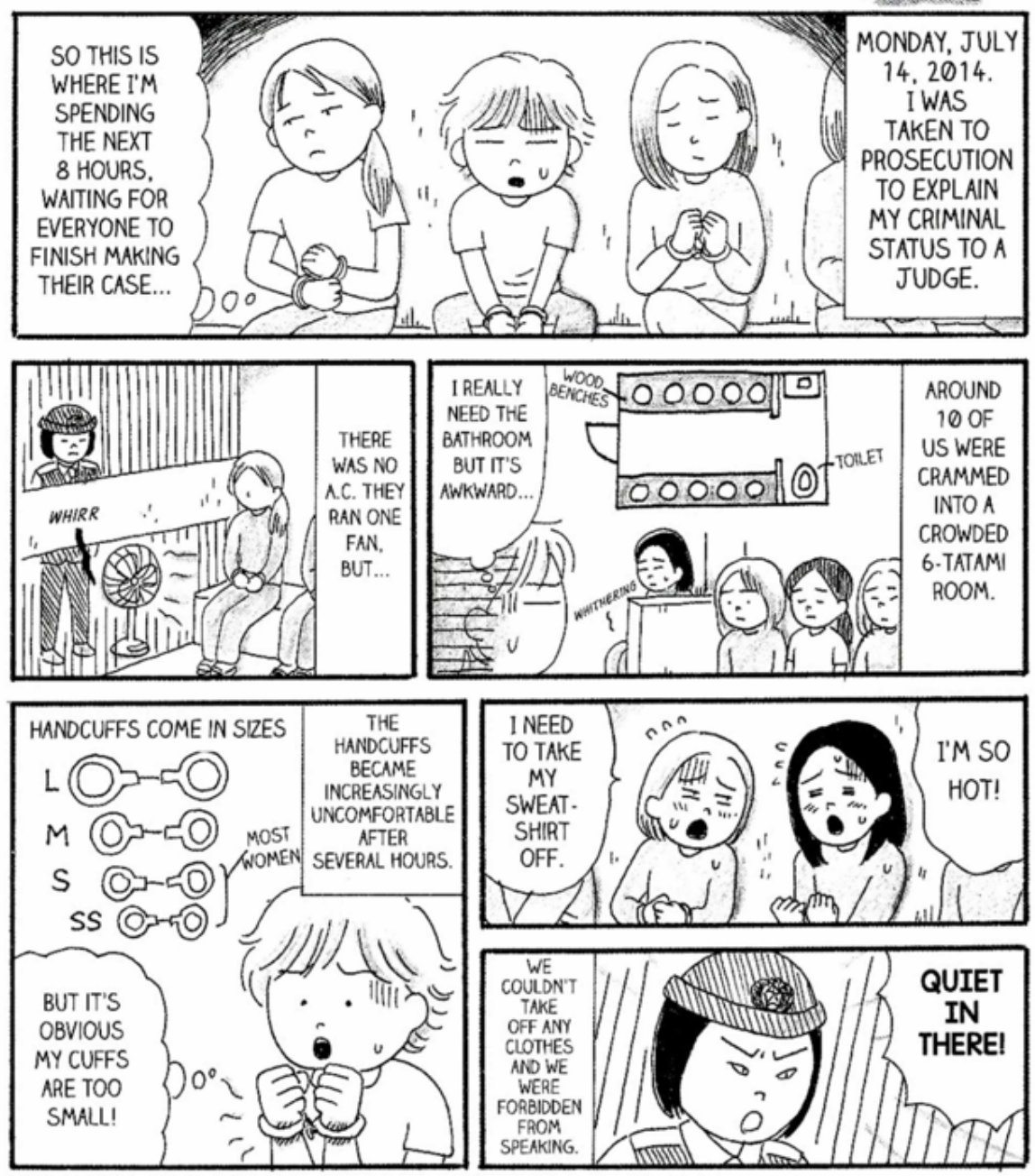

Figure 5. 'Monday July 14, 2014', Chapter 10 from What is obscenity?: The story of a good for notbing artist and her pussy. Rokudenashiko. 2016. (C) Rokudenashiko. 
The rise in popularity of kawaii consumer goods as well as the custom of dolls as mascots is deeply embedded within Japanese culture (Avella, 2004: 213); Rokudenashiko by creating Ms Manko uses the popularity of cute characters within Japanese society to promote her feminist agenda by communicating publicly her campaign to break the taboo on the depiction of female genitalia in Japan. Thus, this borrowing of cute to create the character Ms Manko ironically juxtaposes the monstrous-feminine interpretation of female genitalia. The cute, pastel pink, anthropomorphic creature with minimal features, eyes that are simple dots which make her look shocked, the open-mouthed expression revealing small teeth, evoking images of the vagina dentata - juxtaposes the appropriation of kawaii aesthetics - 'basic elements of cute: round, little, simple, lovable' (Avella, 2004: 217) - with the monstrousfeminine 'that is shocking, terrifying, horrific, abject' (Creed, 1986: 44). Thus Ms Manko as a comic character can be perceived as a powerful feminist emblem.

Rokudenashiko echoes elements of écriture féminine through her graphic novel. Using a borrowed patriarchal language, her eccentric use of image and text undermine and subvert traditional manga significations. Articulating the repression inherent in phallocentric taboo terminology through her utilisation of a 'monstrous-cute' graphic style, her semiotic (Kristeva, 2002) subverts oppression, exposing women's negative and marginal status in the name of a liberatory project. Rokudenashiko's use of Ms Manko subverts the masculine symbolic and documents the artist's disruption of power using the form of the graphic novel as a form of exploratory language.
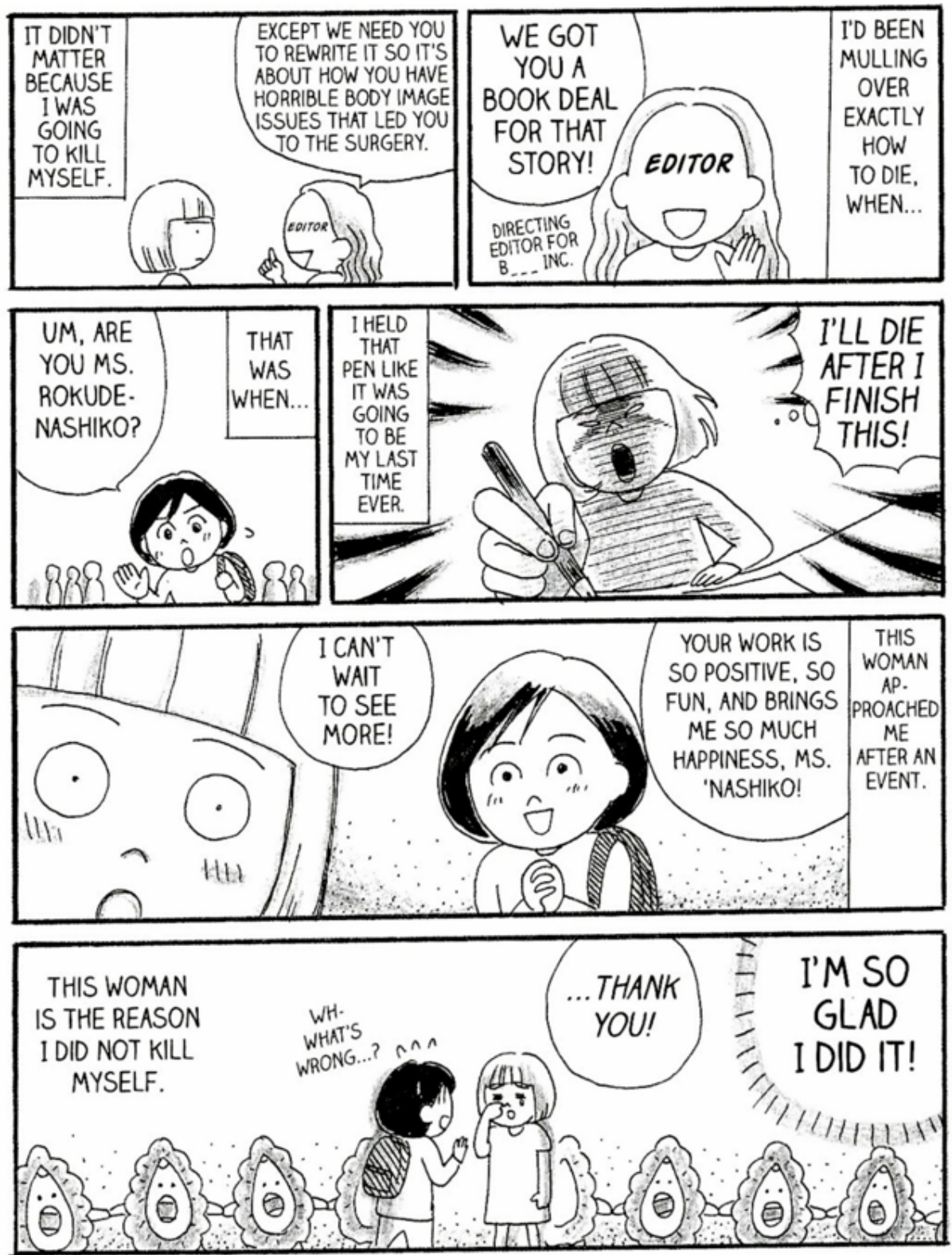

Figure 6. 'Why I became a manko artist', Chapter 5 from What is Obscenity?: The story of a good for nothing artist and her pussy. Rokudenashiko. 2016. (C) Rokudenashiko. 
Throughout Rokudenashiko's account, despite her horrifying ordeal, the contextual information exposing the Japanese legal system and her continued mission to demystify the female body, this manga memoir is presented in a bright and light-hearted way 'Though this way was kind of a joke at first, now I am joking around with every ounce of my body and soul' (Rokudenashiko, 2016: 4) - making her experience and protest wholly relatable to many readers. Her use of direct address - 'Nice to meet you. My name is Rokudenashiko' (Rokudenashiko, 2016: 8) - and her self-reflection as narrator 'I only realised after I started making this work exactly how biased this country was against manko' (Rokudenashiko, 2016: 150) greatly contributes to the value and relatability of her memoir.

\section{CONCLUSION}

By challenging the idea that a woman's body is a medium for promoting national economic growth using artistic forms that rely on digital materialities, she [Rokudenashiko] extends the feminist critiques of women's relation to property that began in the 1970s (McKnight, 2017: n.p.).

The context in which What is Obscenity? (2016) was written and published speaks to the success of this feminist protest graphic memoir. This article has highlighted the significance of Rokudenashiko's appropriation of kawaii and the manga memoir as a way of articulating her feminist message, given the centrality in popular culture both of cuteness and the graphic novel genre, and the extent to which these elements have flourished and been widely embraced not only on a national but on a global platform. Through her use of the graphic novel, Rokudenashiko transforms the genre to which she contributes, as well as re-situating global comics more generally as an emergent textual form for women. Utilising a multidisciplinary approach clearly demonstrates, here, the empowerment that Rokudenashiko projects through textual means. Consequently, the significance of the manga memoir lies in its potential for staging an autobiographical feminist protest narrative, reinforcing the assertion that 'all autobiographical comics have a persuasive purpose' (El Refaie, 2012: 179). Rokudenashiko's identity as a feminist artist is articulated in the manga memoir narrative throughout the portrayal of herself and through the presence of Ms Manko. Successfully appropriating and in turn subverting kawaii practices, her use of a combination of semiotic modes in visual and literary representation demonstrate that sequential cartoon strips and texts are invaluable resources for the construction of autobiographical narratives of feminist activism and critique. To this end, What is Obscenity? (2016) revives and updates the sexual politics of second-wave feminism, thus demonstrating the power and potential of the Japanese manga memoir as contemporary feminist activism.

\section{REFERENCES}

Adams, K. (1999). The way we were. Women's Review of Books, $16(12), 8$.

Aldama, F. L. (2019). Introduction to focus: Graphic nonfiction. American Book Review, 40(2), 3.

Avella, N. (2004). Graphic Japan: From woodblock and Zen to manga and kawaii. Brighton, UK: RotoVision.

Barry, J. and Flitterman, S. (1980). Textual strategies: The politics of art making. Screen, 21(2), 35-48.

Bouissou, J.M. (2008). Why has manga become a global cultural product? Esprit, 7, 42-55. Available at: https://www.cairn-int.info/article-E_ESPRI_346_0042--why-has-manga-become-a-global-cultural.htm (Accessed: 18 February 2020).

Bramlett, F., Cook, R. and Meskin, A. (2016). The Routledge Companion to Comics. New York: Routledge.

Brooks, A. (2002). Postfeminisms: Feminism, cultural theory and cultural forms. London: Routledge.

Bulbeck, C. (1998). Re-orienting Western Feminisms: Women's diversity in a postcolonial world. Cambridge, UK: Cambridge University Press.

Chute, H. (2008). Comics as literature? Reading graphic narrative. PML A, 123 (2), 452-465.

Cixous, H. (2004). The newly born woman. In Rivkin, J. and Ryan, M. (eds.), Literary Theory: An anthology (pp. 348 - 354). London: Blackwell Publishing Ltd.

Cocca, C. (2014). The 'Broke Back Test': a quantitative and qualitative analysis of portrayals of women in mainstream superhero comics, 1993-2013. Journal of Graphic Novels and Comics, 5(4), 411-428.

Creed, B. (1993). The Monstrous-Feminine: Film, feminism, psychoanalysis. London: Routledge.

Creed, B. (1986). Horror and the monstrous-feminine: An imaginary abjection. Screen, 27(1), 44-71.

De Beauvoir, S. (1949/2011). The Second Sex (translated and revised by C. Borde and S. Malovany-Chevallier). New York, NY: Vintage Books.

Duncan, R., Smith, M. J. and Levitz, P. (2015). The Power of Comics: History, form, and culture. London: Bloomsbury Publishing.

Eisner, W. (2008). Comics and Sequential Art: Principles and practices from the legendary cartoonist. New York, NY: WW Norton and Company.

$14 / 16$

(C) 2020 by Author/s 
El Refaie, E. (2012). Autobiographical Comics: Life writing in pictures. Jackson: University Press of Mississippi.

Evans, J. (1995). Feminist Theory Today: An introduction to second-wave feminism. Newbury Park, California: Sage.

Fairclough, N. (2013). Critical Discourse Analysis: The critical study of language. New York: Routledge.

Fairclough, N. (1995). Critical Discourse Analysis. London: Longman.

Fairclough, N. (1993). Critical discourse analysis and the marketization of public discourse: The universities. Discourse \& Society, 4(2), 133-168.

Freud, S. (1909). Analysis of a phobia in a five-year old boy. In Strachey, J. (Ed. \& Trans.), The Standard Edition of the Complete Psychological Works of Sigmund Freud (Vol. 10, pp. 1-150). London: Hogarth Press.

Gardner, J. (2012). Projections: Comics and the history of twenty-first-century storytelling. Stanford, CA: Stanford University Press.

Groensteen, T. (2007). The System of Comics. Jackson: University Press of Mississippi.

Groensteen, T. (2013). Comics and Narration. Jackson: University Press of Mississippi.

Gwynne, J. (2013). Japan, postfeminism and the consumption of sexual(ised) schoolgirls in male-authored contemporary manga. Feminist Theory, 14(3), 325-343.

Heilbrun, C. G. (1999). Contemporary memoirs: Or, who cares who did what to whom? The American Scholar, 68(3), 35-42.

Irigaray, L. (1985). Speculum of the Other Woman. Ithaca, NY: Cornell University Press.

Jones, A. (1998). Body Art/ Performing the Subject. Minneapolis, Minnesota: University of Minnesota Press.

Knafo, D. (2009). In Her Own Image: Women's self-representation in twentieth-century art. New Jersey: Fairleigh Dickinson University Press/Associated University Presses.

Kano, A. (2018). Womenomics and acrobatics: Why Japanese feminists remain skeptical about feminist state policy. Feminist Encounters: A Journal of Critical Studies in Culture and Politics, $2(1), 6$. https://doi.org/10.20897/femenc.201806

Kinsella, S. (2013). Cuties in Japan. In Moeran, B. and Skov, L. (eds). Women, Media and Consumption in Japan (pp. 220-254). London: Routledge.

Kress, G. and van Leeuwen, T. (2006). Reading Images: The grammar of visual design. London: Routledge

Kristeva, J. (2002). The Portable Kristeva. New York: Columbia University Press.

Lippard, L. (1989). Both sides now (a reprise). Heresies, 24, 29.

Lippard, L. R. (1980). Sweeping exchanges: the contribution of feminism to the art of the 1970s. Art Journal, 40(12), 362-365.

Mackie, V. (1988). Feminist politics in Japan. New Left Review, 167(5), 3-76.

Malek, A. (2006). Memoir as Iranian exile cultural production: A case study of Marjane Satrapi's Persepolis series. Iranian Studies, 39(3), 353-380.

McAllister, M. P., Sewell, E. H. and Gordon, I. (2001). Introducing comics and ideology. Comics and ideology, pp.113.

McCloud, S. (1994). Understanding Comics: The invisible art. New York: HarperCollins.

McKnight, A. (2017). At the source (code): Obscenity and modularity in Rokudenashiko's media activism. In M. Steinberg and A. Zalten (eds.), Media Theory in Japan. Durham: Duke University Press.

Meskimmon, M. (2012). Women Making Art: History, subjectivity, aesthetics. New York: Routledge.

Meskimmon, M. (2008). Feminisms and art theory. In Smith, P. and Wilde, C. (eds.), A Companion to Art Theory (pp.380 - 396). Oxford: Wiley Blackwell.

Miller, N. K. (2000). But enough about me, what do you think of my memoir? The Yale Journal of Criticism, 13(2), 421-436.

Murray, R. (2011). The feminine mystique: Feminism, sexuality, motherhood. Journal of Graphic Novels and Comics, 2(1), 55-66.

Nochlin, L. (1971/2003). Why have there been no great women artists? In Jones, A. (ed.), The feminism and visual culture reader (pp. 229-233). London: Psychology Press.

Panchanathan, S., Park, Y. C., Kim, K. S., Kim, P. K. and Golshani, F. (2000). September. The role of color in content-based image retrieval. In Proceedings 2000 International Conference on Image Processing (Cat. No. 00CH37101) (Vol. 1, pp. 517-520). IEEE.

Pollock, G. (2013). Differencing the Canon: Feminism and the writing of art's histories. London: Routledge.

Pollock, G. (ed.). (2005). Generations and Geographies in the Visual Arts: Feminist readings. London: Routledge.

Roces, M. (2010). Asian feminisms: Women's movements from the Asian perspective. In Roces, M. and Edwards, L. (eds.), Women's Movements in Asia: Feminisms and transnational activism (pp. 11-30). New York: Routledge.

Rokudenashiko. (2016). What is obscenity?: The story of a good for nothing artist and her pussy. Toronto, Canada: Koyama Press.

Royal, D. P. (2007). Introduction: Colouring America: Multi-ethnic engagements with graphic narrative. MultiEthnic Literature of the United States (MELUS), 32(3), 7-22. 
Sabin, R. (2013). Adult Comics: An introduction. London: Routledge.

Sanders, L. S. (2007). Feminists love a utopia. In Gillis, S., Howie, G. and Munford, R. (eds.), Third Wave Feminism (pp. 3-15). London: Palgrave Macmillan.

Satrapi, M. (2008). Persepolis I and II. London: Random House.

Simone, G. (1999). Women in Refrigerators. Available at: http://web.archive.org/web/20120111060731/ http:/ /www.unheardtaunts.com/wir/ (Accessed: 18 February 2020).

Skidmore, M. J. (1983). More than mere fantasy. Journal of Popular Culture, 17(1), 83-92.

Taylor, J. (2008). The problem of women's sociality in contemporary North American feminist memoir. Gender \& Society 22(6) 705-727.

Thorn, M. (2004). Girls and women getting out of hand: The pleasure and politics of Japan's amateur comics community. In Kelly, W. (ed.), Fanning the Flames: Fans and consumer culture in contemporary Japan (pp.169-188). New York: State University of New York Press.

Tierney, H. (1996). Hannah Wilke: The intra-Venus photographs. Performing Arts Journal, 18(1), 44-49.

Wilke, H. (1974). SOS Starification 1974 - 1982. Hannah Wilke Collection \& Archive, Los Angeles, CA. URL: Available at: http://www.hannahwilke.com (Accessed: 18 February 2020).

Whitlock, G. (2006). Autographics: The seeing 'I' of the comics. Modern Fiction Studies, 52(4), 965-979.

Zack, N. (2005). Inclusive Feminism: A third wave theory of women's commonality. Lanham, Maryland: Rowman \& Littlefield.

Citation: Sylvester, S. (2020). Drawing Dangerous Women: The Monstrous-Feminine, Taboo and Japanese Feminist Perspectives on the Female Form. Feminist Encounters: A Journal of Critical Studies in Culture and Politics, 4(1), 05. https://doi.org/10.20897/femenc/7909

Copyright (C) 2020 by Author/s and Licensed by Lectito BV, Netherlands. This is an open access article distributed under the Creative Commons Attribution License which permits unrestricted use, distribution, and reproduction in any medium, provided the original work is properly cited. 